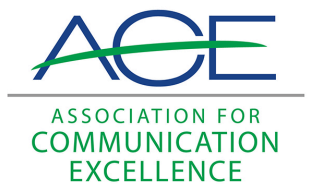

Journal of Applied Communications

\title{
Magazine Executives See Bright Future; Communicatlon Responsibilities of the International Agricultural Research Centers; llustrations for Development: A Manual for Cross-Cultural Communication through Illustration and Workshops for Artists In Africa; A Q Study of Attitudes of Young Adults About Science and Science News
}

Myrna Daly

Paul Gwin

James W. King

See next page for additional authors

Follow this and additional works at: https://newprairiepress.org/jac

(c) (1)(2)

This work is licensed under a Creative Commons Attribution-Noncommercial-Share Alike 4.0 License.

Recommended Citation

Daly, Myrna; Gwin, Paul; King, James W.; and Shaner, Jim (1983) "Magazine Executives See Bright Future; Communicatlon Responsibilities of the International Agricultural Research Centers; llustrations for Development: A Manual for Cross-Cultural Communication through Illustration and Workshops for Artists In Africa; A Q Study of Attitudes of Young Adults About Science and Science News," Journal of Applied Communications: Vol. 66: Iss. 3. https://doi.org/10.4148/1051-0834.1723

This Review is brought to you for free and open access by New Prairie Press. It has been accepted for inclusion in Journal of Applied Communications by an authorized administrator of New Prairie Press. For more information, please contact cads@k-state.edu. 


\title{
Magazine Executives See Bright Future; Communicatlon Responsibilities of the International Agricultural Research Centers; llustrations for Development: A Manual for Cross-Cultural Communication through Illustration and Workshops for Artists In Africa; A Q Study of Attitudes of Young Adults About Science and Science News
}

\author{
Abstract \\ Reviews of "Magazine Executives See Bright Future," in Folio: The Magazine for Management, \\ "Communicatlon Responsibilities of the International Agricultural Research Centers," published by \\ Agricultural Development Council, Inc., and the International Rice Research Institute; llustrations for \\ Development: A Manual for Cross-Cultural Communication through Illustration and Workshops for Artists \\ In Africa, edited by G. McBean, N. Kaggwa, and J. Bugembe; "A Q Study of Attitudes of Young Adults \\ About Science and Science News," by Joye Patterson. \\ Authors \\ Myrna Daly, Paul Gwin, James W. King, and Jim Shaner
}




\section{Reviews}

“Magazine Executives See Bright Future," Folio: The Magazine for Magazine Management,"' (September, 1982).

Those of us wondering about the future of our own communications efforts can get a glimpse of the crystal ball used by 24 magazine publishing executives interviewed for the 10th anniversary issue of Folio: The Magazine for Magazine Management.

If you're pondering the future of publications in an era of cost recovery programs, for example, note the view of Kelso F. Sutton of Time inc. Even in periods of eroding disposable income, he says, consumers are interested in "truly useful printed information." Sutton cites a.Paine Webber analyst who says the dollars spent on published materials as a percentage of GNP has grown at a relatively fixed rate.

What price in-house typesetting?

The system described by Frank Romano, publisher of the New England Printer and Publisher, will "look like an office copier" and cost "less than the 1992 Buick." It will not only produce completely typeset pages, including photos and illustrations, but will also check spelling, grammar and copyright, and can even supply a list of synonyms and famous quotations for the blocked writer.

Romano predicts that, using expanded versions of today's technology, "every person on earth can be addressed directly," either by using the personal identification codes for their video terminals or by using a 23-digit Zip Code. Computer and electronic hardware will continue to drop in price while increasing in performance, Romano says.

"It will not be typesetting so much that will direct future directions but the entire field of information distribution."

Home computers are a "given" as the next generation learns how to use them. But even Ellen M. Poler, electronic publishing manager for McGraw-Hill publications, believes "traditional print 
journalism will continue to thrive, because computers are neither portable nor 'browsable,' and it's hard on the eyes to read several thousand words from a computer screen or printout."

Writers and editors, take heart.

Myrna Daly

Kansas State University

\begin{abstract}
"Communication Responsibilities of the International Agricultural Research Centers." Published by Agricultural Development Council, Inc., and the International Rice Research Institute (IRRI), P.O. Box 933, Los Banos, Laguna, Phillppines.
\end{abstract}

This conference presents some much needed and well thought-out guidelines for communication programs at international agricultural research centers. The conference, held at IRRI in the Philippines, was attended by communicators from all 13 international agricultural research centers, and included four international center directors, 14 communicators from universities, and a sprinkling of scientists, training officers and extension specialists.

The soundness of the emerging guidelines, we'd like to think, are due to some well known ACE members, whose names appear on the roster of delegates, i.e., Jim Bemis, CIMMYT (in Mexico); Francis Byrnes, IADS (Washington, DC); Tom Hargrove, IRRI; Grant Johnson, AVRDC (in Taiwan), formerly on Nebraska staff; Bryant Kearl, Wisconsin; Bob Kern, lowa; Walt Rockwood, now/AID; and John Woods, U.N. Development Training and Communications Planning, head, Asia branch, Bangkok, formerly of Illinois editorial staff.

Delegates split into five work groups to make recommendations on: Facilitating Scientist-to-Scientist Information Flow; Keeping Donors, Policy Makers, and the Public Informed; Training, Support, and Development of National Communication Staff; Communication Research and Evaluation; and Communication Relationships with National Agricultural Programs.

The report is well edited-right down to the bare essentials for communication planning in each of these communication service areas. The document should be a big help to editorial staffs of the international centers in explaining to administrators the need to broaden the centers' communication reach. 
Older ACE members can appreciate such recommendations as getting away from publishing the huge annual report summarizing every research project at the center. Instead, the committee suggested converting to means of reporting to each specialized audience on progress in their field of interest. It took a long time to bring some of our deans around to this way of thinking.

in the beginning, when there wasn't much research to talk about, it was probably good strategy to bulk reports in a big, fancy package, giving the impression of a heavy research contribution. But there is little of real interest to any one person in these weighty tomes, and they sound alike from one year to the next.

In their formative years, the centers were wrapped up in internal and scientist-to-scientist communication. Now that they have developed many adapted crop and livestock varieties and systems they are feeling the urge, as well as pressure from the outside, to make more effort to get their information to people who can use it.

Paul Gwin, retired University of Missouri-Columbia

Illustrations for Development: A Manual for Cross-Cultural Communication through Illustration and Workshops for Artists in Africa. Edited by G. McBean, N. Kaggwa, and J. Bugembe Afrolit Papers No. 6, Afrolit Society, P.O. Box 72511, Nairobi, Kenya.

This volume aims to improve the visual element of development communications by offering ways and means of providing more communicative illustrations. Through research based guidelines, examples and practical exercises, the editors hope to have artists make illustrations with reference to the target audience, the people who are supposed to receive meaning and benefit from the illustrations.

Teamwork in message design and production is emphasized in the first section. For the artist, this means that his work is part of a total communication effort. Since about 70 percent of the population of sub-Saharan Africa is estimated to be illiterate, or only semi-literate, the demand for relevant visuals is a very considerable part of the development effort. Based on this, the lack 
of mass media, which may be inappropriate for many development messages, the illustration can provide a very effective medium for development messages. Twenty-three research conclusions which should be considered by an artist when illustrating for an audience with little experience with two dimensional representations are also presented. For example: close up illustrations which cut off any part of the body (e.g, head or hands) are difficult to comprehend; symbols such as ticks, crosses, arrows, pain symbols, lines for speed, or movement for heat or fever, shaky lines for chills, dotted lines for flight, are not understood by the new viewer and must be introduced slowly and patiently.

Next the illustrator's role in relation to the subject matter is discussed and ways to structure messages for particular audiences are examined. In particular, emphasis is given to the difference in drawing for the target audience as compared to art lovers, friends, and bosses. The editors are very serious in their emphasis on designing materials for specific audiences, and the processes to do so. Levels of visual perception, information quantity, audience segmentation, local customs and traditions, community groupings, physical environments, and previous knowledge about the topic are criteria to use in developing visual materiais.

Artistic skills for development illustration is presented in the third section through a series of exercises in realistic drawings. Practical assignments are also given, such as the design of a poster illustrating a well balanced diet. The editors stress the importance of redoing work which is not quite acceptable, a perpetual bone of contention for the creative artists.

Section four continues this point when it outlines pretesting methods for drawings. Sample questions are given, together with the original illustrations and the revised illustrations. Reproduction techniques are also noted in this section so that the artist will understand and have some knowledge of the printing process. Lettering recommendations and legibility standards are given. Finally, the relationship between the artist and the development team in terms of deadlines and work schedules is discussed.

The last section features illustrations for development as a career and offers five suggestions to improve visuals. 
This a valuable book because it discusses an urgent need-the design and development of visuals in multicultural environments; excellent visuals are used throughout. It is also valuable because it was developed in Africa, indicating the continued growing independence of local communicators away from Western culture: local people discussing their own problems and offering their own solutions from their own perspectives.

James W. King

University of Hawaii

\section{"A Q Study of Attitudes of Young Adults About Science and} Science News," by Joye Patterson, Journalism Quarterly, 59:3 (August, 1982), p. 406-413.

Despite studies that show science as "again one of the hot interests of young people," Joye Patterson notes science coverage has changed little over the last two decades. It still fills less than 6 percent of the news hole. She reasons that editors and publishers concerned about declining circulation might pique the scientific curiosity of those $18-34$ by publishing more science news.

To help us do that, the teacher of science writing explores the attitudes of this group about science and attempts to gather clues about their media habits regarding it.

The associate professor of journalism employs $Q$ technique. Oversimplifying, it's a small sample approach that uses factor analysis to discover types of people, based upon their agreement or disagreement with opinion statements on an issue.

She found three types: a true believer who sees science as the pathway to the future," an anxious dissenter who sees "reason to be apprehensive about science and technology," and a seasoned supporter who "applaud(s) science for its achievements, but view(s) it ... as one part of the larger scene."

Patterson, a co-editor of Sciphers, a newsletter for teachers of science writers, says her study is too small to draw broad implications. But she offers some clues regarding the interest those 18-34 have in science and makes some suggestions for further study. The $Q$ technique itself was supplemented by information on those surveyed from two questionnaires-one on 
Journal of A pplied Communications, Vol. 66, Iss. 3 [1983], Art. 5

demographics, another on their media preferences related to science.

It offers agricultural communicators some ammunition for their science writing efforts and a look at $Q$ technique.

Jim Shaner

University of Missouri 
Daly et al.: M agazine Executives See Bright Future; Communicatlon Responsibili 
Journal of Applied Communications, Vol. 66, Iss. 3 [1983], Art. 5

https://newprairiepress.org/jac/vol66/iss3/5

DOI: $10.4148 / 1051-0834.1723$ 